\author{
하수종말처리장의 인 처리시설에 티탄염 응집제 적용 및 슬러지 재활용 \\ 김종범 · 박희주* · 이기원* · 조아라* · 김명완* · 이영준 · 박세민 · 이광영* · 손호경** · 김종호 ${ }^{\dagger}$ \\ 전남대학교 응용화학공학부, 촉매연구소 \\ 500-757 광주광역시 북구 용봉동 300 \\ *(주)빛과환경 \\ 500-460 광주광역시 북구 월출동 970-5 \\ **시드니공과대학교 토목환경공학부 \\ 브로드웨이, 뉴샤우스 웨일즈, 2007 호주 \\ (2012년 11월 27일 접수, 2012년 12월 23일 채택)
}

\title{
Application of Ti-salt Coagulant and Sludge Recycling for Phosphorus Removal in Biologically Treated Sewage Effluent
}

\author{
Jong Beom Kim, Hee-Ju Park*, Ki Won Lee*, A Ra Jo*, Myung Wan Kim*, Young Jun Lee, Se Min Park, \\ Kwang Young Lee*, Ho Kyong Shon** and Jong-Ho Kim ${ }^{\dagger}$ \\ School of Applied Chemical Engineering and The Research Institute for Catalysis, Chonnam National University, \\ 300 Yongbong-dong, Buk-gu, Gwangju 500-757, Korea \\ *Photo \& Environmental Technology Co., Ltd., 970-5 Woulchul-dong, Buk-gu, Gwangju 500-460, Korea \\ **Faculty of Engineering, University of Technology, Sydney, P.O. Box 123. Broadway, NSW 2007, Australia \\ (Received 27 November 2012; accepted 23 December 2012)
}

\begin{abstract}
요 약
부영양화 방지를 위하여 규제되는 총인(Total-phosphorous, T-P) 농도가 $0.2 \sim 2 \mathrm{mg} / \mathrm{L}$ 이하로 변경됨에 따라, 응집 처 리 과정에서 인의 제거를 시도하게 되었다. 따라서 본 연구는 실제 하수종말처리장의 생물학적 처리수를 시료로 하여 티탄염 농도, $\mathrm{pH}$ 등의 인자가 인 제거에 미치는 특성에 대하여 검토하였다. 또한 실제 현장에서 가장 많이 사용되는 침강식 침전조와 가압부상식 침전조에 티탄염을 적용하여 인 제거 효율 및 슬러지 활용 가능성을 조사하였다. 응집제 로 티탄염을 사용하는 경우 인 제거효율이 기존에 사용하는 황산 알루미늄 $\left(\mathrm{Al}_{2}\left(\mathrm{SO}_{4}\right)_{3}\right.$, Alum)과 유사하였다. 하향 침강 방식의 침전조와 가압부상방식의 침전조 모두 기준치 이하로 모두 현장 적용이 가능하였다. 생성된 산화티탄의 성분 은 원수에 포함된 무기물과 투입된 티탄염 성분으로 구성되었다. 티탄염 응집 후 생성된 슬러지를 소성하여 산화티탄 을 제조하였다. 시판되고 있는 P-25 제품과 유사한 광촉매 활성을 가지고 있어 슬러지에서 생성된 산화티탄도 기존에 사용하는 제품시장에 대체 사용이 가능할 것으로 판단된다.
\end{abstract}

\begin{abstract}
As the regulation of total phosphorus (T-P) concentration in biologically treated sewage effluent is reduced to $0.2 \sim 2 \mathrm{mg} / \mathrm{L}$, flocculation process is recommended to remove T-P. In this study, the performance of Tisalt coagulant was investigated in terms of dosage and $\mathrm{pH}$ in removing phosphorus and the collected sludge after Ti-salt flocculation was calcined to produce titania for effective sludge recycling. The flocculation performance was carried out using two methods: sedimentation and air floatation. Both methods were feasible to apply for Tisalt flocculation. Ti-salt flocculation was effective in reducing phosphorus concentration in sewage effluent, which showed similar performance of alum $\left(\mathrm{Al}_{2}\left(\mathrm{SO}_{4}\right)_{3}\right)$. The calcined sludge was recycled to titania which is the widely used metal oxide. Titania produed from Ti-salt sludge indicated similar charateristics of commercially-available P25 in regard to photocatalytic activity and surface area. Therefore, this can be easily adopted to titania application by replacing P-25.
\end{abstract}

Key words: Phosphorus, Ti-salt Coagulant, Wastewater, Sludge Recycling, Titania

\footnotetext{
${ }^{\dagger}$ To whom correspondence should be addressed.

E-mail: jonghkim@chonnam.ac.kr

†이 논문은 전남대학교 서곤 교수님의 정년을 기념하여 투고되었습니다.
} 


\section{1. 서 론}

인은 지구 표면에 풍부한 물질로 인산 $\left(\mathrm{PO}_{4}^{3-}\right)$ 형태로 토양이나 물 에 존재한다[1,2]. 특히 수질 상에서 무기성 인, 유기성 인, 입자상 인 으로 구분되며, 이들을 통칭하여 총인(Total-phosphorous, T-P)이라 한다. 인은 생명체의 성장에 필수적인 요소이지만, 농도가 높아지면 부영양화를 유발하여 조류 등의 증식으로 수질오염의 원인이 된다 [2,3]. 국내에서는 부영양화 방지를 위하여 T-P 배출허용 기준을 하 루 하수처리용량 $50 \mathrm{~m}^{3}$ 기준으로 $2 \sim 4 \mathrm{mg} / \mathrm{L}$ 이하에서 권역 별로 $0.2 \sim 2 \mathrm{mg} / \mathrm{L}$ 이하로 변경하였다. 특히 4대강 유역의 하수종말처리장 의 방류기준은 대부분 $0.2 \mathrm{mg} / \mathrm{L}$ 이하로 대폭 강화되었다. 하수에 포 함된 인을 제거하는 방법으로는 알루미늄염, 철염 등을 응집제로 이 용하는 화학적 처리 방법과 생물화학적 처리 방법 등이 적용되고 있 다. 화학적 처리로 인한 인 제거 방법은 알루미늄염이나 철염을 이 용하여 정인산염과 고형물에 함유된 다른 형태의 인으로 함께 제거 할 수 있다[3]. 일반적인 생물학적 공정에서 제거 가능한 인 제거 농 도는 최대 $1 \mathrm{mg} / \mathrm{L}$ 로 알려져 있다[4]. 따라서 강화되는 인 제거 수질 목표를 달성하기 위해서는 생물학적 처리와 화학적 처리가 병행되어 야 한다. 일반적인 처리 순서는 생물학적 처리공정 후단에 화학적 공 정을 추가하여 인을 제거하는 공정을 채택하고 있으며, 이러한 설비 는 비교적 간단하게 설치가 가능하고 수질 변화에 따라 대처가 용이 하다는 장점을 갖는다. 실제적으로 일본의 경우에는 생물학적 처리 와 화학적 처리를 병행하여 T-P $0.02 \mathrm{mg} / \mathrm{L}$, 생물학적 산소요구량 (Biochemical Oxygen Demand, BOD) $1 \mathrm{mg} / \mathrm{L}$, 화학적 산소요구량 (Chemical Oxygen Demand, COD) $5 \mathrm{mg} / \mathrm{L}$ 정도까지 수질을 향상시 키는 것으로 알려져 있다. 국내 대부분의 하수종말처리장은 유입되 는 인의 농도가 높지 않아 기존의 인 배출 기준을 생물학적 처리만 으로도 달성할 수 있었다. 하지만 강화되는 기준을 만족하기에는 생 물학적 공정만으로 목표 달성이 어려워 화학적 공정의 추가 설치가 요구되고 있다. 정부는 이러한 현장의 실태를 반영하여 화학적 공정 설비 구축을 중심으로 하는 하-폐수처리장의 인 처리시설을 237개소 증설하기로 하고, 이 중 $85 \%$ 를 2011년까지 완공하여 2012년 강화되 는 수질 기준을 달성하기 위한 계획을 수립하였다[5]. 하지만 이러한 인 총량제 수질 목표 달성을 위하여 화학적 처리공정을 증설하게 되 면 몇 가지 문제점이 발생하게 된다. 일차적으로 운영비가 상승한다. 화학적 처리에 소요되는 약품 비용, 탈수 슬러지 증가분에 따른 탈 수 약품비 및 슬러지 처리비용이 증가하며, 이차적으로는 인 제거를 위하여 투입되는 약품에 의한 슬러지에 포함되는 금속 성분이 증가 하는 것이다.

현재 하수처리시설에서 발생하는 대부분의 슬러지는 해양투기나 매립 방법으로 처리하고 있다. 하지만, 해양투기의 경우에는 국제 조 약에 의하여 그 배출이 점차 제한되고 있으며, 조만간에 전면 금지 될 예정이다. 따라서 현재 해양 배출되는 슬러지는 육상에서 전량 처 리하여야 한다. 하수 슬러지의 육상 처리 방법은 크게 매립이나 재 활용으로 집중될 것으로 예상된다. 이렇게 되면 슬러지 처리량의 증 가에 의한 슬러지 처리 단가가 상승하게 된다. 따라서 인 제거로 인 한 슬러지의 증가는 보다 많은 비용 부담이 될 수밖에 없다. 또한 인 제거를 위하여 투입되는 약품으로 인한 슬러지에 포함되는 금속물질 들은 처리나 재활용을 곤란하게 할 수 있다. 특히 인 제거를 위하여 가장 많이 사용되는 Alum, PAC (Polyaluminium chloride) 등의 알 루미늄 계열의 응집제들은 우리에게 알츠하이머 병 등을 유발하거나
동식물 고사 등의 악영향을 줄 수도 있다[6,7].

이러한 기존 응집제의 문제점과 발생하는 슬러지 처리 문제점을 해결하기 위하여 기존 응집제를 대체할 수 있는 약품으로 티탄염 응 집제를 제시한 바 있다[8]. 티탄염 응집제를 사용하는 경우 물 속에 포함된 인을 효과적으로 제거할 수 있는 것으로 알려져 있으며, 발 생하는 슬러지에 포함된 티탄 성분을 재활용하여 산화티탄을 생산할 수 있다. 하지만 이러한 연구들이 표준폐수에 인을 투입하고 이를 대 상으로 실험을 진행한 것임으로 실제 현장 적용 여부는 단언하기 어 렵다.

따라서 본 연구는 실제 하수종말처리장의 생물학적 처리수를 시 료로 하여 티탄염 농도, $\mathrm{pH}$ 등의 인자가 인 제거에 미치는 특성에 대 하여 검토하였으며, 이를 통하여 현장에 적용 가능한 인 제거 조건 을 도출하였다. 또한 실제 현장에서 가장 많이 사용되는 침강식 침 전조와 가압부상식 침전조에 티탄염을 적용하여 인 제거 효율 및 슬 러지 활용 가능성을 분석하였다.

\section{2. 실 험}

실험실에서 진행한 Jar 테스트와 실제 하수종말처리장에서 진행한 현장테스트를 실시하였다. 시료는 낙동강 수계에 위치한 $\mathrm{C}$ 하수종말 처리장과 영산강 수계에 위치한 $\mathrm{S}$ 하수종말처리장에서 생물학적 처 리수를 취수하여 사용하였다. 실험에 사용한 Alum은 이화산업 제품 으로 $\mathrm{Al}_{2}\left(\mathrm{SO}_{4}\right)_{3}$ 의 함량이 $12 \%$ 이며, 티탄염은 (주)빛과환경의 TC-20 제품으로 $\mathrm{TiCl}_{4}$ 함량이 $20 \%$ 이다. Jar 테스트는 시료 $2 \mathrm{~L}$ 를 비이커에 담아 Alum 또는 티탄염을 투입하고 Jar tester에서 $100 \mathrm{rpm}$ 으로 1분 간 급속 교반하고, $30 \mathrm{rpm}$ 으로 10 분간 완속 교반한 후 상등액을 채 취하였다. 응집 전후의 시료에 대하여 $\mathrm{pH}$ 와 T-P를 측정하였으며, T-P 측정은 Standard Method (digestion \& stannous chloride method)에 따라 분석하였다[9]. 필요에 따라 시료를 Glass Fiber Cloth (GFC) $(0.4 \mu \mathrm{m})$ 로 여과한 시료로 인 농도를 측정하였다. Alum과 티탄염 (TC-20)의 투입량을 변화시키면서 실험을 진행하였다. 각 약품의 투 입량은 부피단위 $(\mathrm{ml})$ 로 진행하였다. 현장테스트는 가압부상조가 설치 된 $\mathrm{C}$ 하수종말처리장의 경우 설치된 기존 설비를 활용하여 실험하였 다. 침강조가 설치된 $\mathrm{S}$ 하수종말처리장의 경우에는 침강식 파일롯을 사용하여 진행하였다. 가압부상식 고도처리설비의 용량은 $6,000 \mathrm{~m}^{3} /$ day이며, 침강식 파일롯 설비의 용량은 $24 \mathrm{~m}^{3} / \mathrm{day}$ 이다. 현장테스트 시료도 Jar 테스트 시료와 동일한 방법으로 $\mathrm{pH}$ 와 T-P를 측정하였다. $\mathrm{C}$ 하수종말처리장의 경우에는 고정된 투입량으로 4일 동안 테스트를 진행하였으며, S 하수종말처리장에 설치한 파일롯 장비에서는 투입 량을 매일 변경하면서 9 가지 조건에서 9 일간 테스트를 진행하였다. 기준치에 만족하는 조건에서 생성된 슬러지는 $300{ }^{\circ} \mathrm{C}$ 에서 함수율 $10 \%$ 미만까지 일차 건조하고, $2{ }^{\circ} \mathrm{C} / \mathrm{min}$ 속도로 목표 온도까지 승온 하고, 4시간 유지하여 소성하였다.

생성된 분말은 Hitachi 사 S-4700 모델의 SEM/EDX 장비로 분석 하여 성분 함량을 확인하였으며, 적정 소성 온도를 확인하기 위한 생 성 분말의 구조 분석은 $\mathrm{CuK \alpha} \mathrm{X}$-선 $(\lambda=1.54056 \AA)$ 과 Ni-filter를 사용 한 X-선 회절분석기(X-ray diffractometer; Rigaku, D/MAX Uitima $\mathrm{III}$ 로 $40 \mathrm{kA}$ 와 $40 \mathrm{~mA}$ 조건에서 $\mathrm{X}$-선 회절패턴을 그렸다.

광촉매 활성을 평가하기 위하여 직접 제작한 고정식 반응기(220 $\times 125 \times 80 \mathrm{~mm}$ )와 기체크로마토그래프(Gas-chromatograph, HP-5900)를 이용하여 아세트알데히드 흡착/분해 성능을 측정하였다[8]. 기체크 
로마토그래프는 FID (Flame Ionization Detector) 검출기와 HP-5 컬 럼으로 구성되었다. 기체크마토그래프의 측정 조건으로 주입부와 검 출부의 온도는 $250{ }^{\circ} \mathrm{C}$, 오븐은 $40^{\circ} \mathrm{C}$ 에서 $60^{\circ} \mathrm{C}$ 까지 $5{ }^{\circ} \mathrm{C} / \mathrm{min}, 100{ }^{\circ} \mathrm{C}$ 까지 $2^{\circ} \mathrm{C} / \mathrm{min}$ 의 승온 속도로 설정하였다. 광촉매 $0.5 \mathrm{~g}$ 을 증발접시에 넓게 펴서 반응기 내에 넣고 대상 기체인 아세트알데히드(Foxchemicals, 99.9\%)를 완전히 흡착시킨 후, 아세트알데히드를 2,000 $\mathrm{ppmv}$ 주입하여, 시간에 따른 아세트알데히드 특성 피크의 감소 정 도로 흡착과 분해를 결정하였다. 흡착은 반응기 내의 아세트알데히 드가 더 이상 감소하지 않을 때까지(1시간 정도), 분해는 흡착이 끝 난 후 UV 램프(10 W blacklight 2개, Sankyo Denki)를 켠 후 200분 동안 측정하였다. 응집제의 투입 시 원수의 $\mathrm{pH}$ 조정은 실시하지 않 았으며, 적정 투입량의 결정 및 운전 조건은 각 현장의 운용 기준에 맞추어 실시하였다.

\section{3. 결과 및 고찰}

\section{3-1. 대상별 jar test 결과 및 특성}

$\mathrm{S}$ 하수종말처리장에서 취수한 생물학적 처리수 원수의 $\mathrm{pH}$ 는 6.44 , T-P 농도는 $1.49 \mathrm{mg} / \mathrm{L}$ 였다. 여기에 Alum과 티탄염을 $0.08,0.10,0.15$ $\mathrm{ml} / \mathrm{L}$ 로 투입량을 조절하여 실험을 실시하였다. Fig. 1에 Alum과 티 탄염의 투입량의 따른 T-P 농도를 정리하였다. $0.1 \mathrm{ml} / \mathrm{L}$ 투입하였을 때 티탄염에서 T-P 농도는 $0.30 \mathrm{mg} / \mathrm{L}$, Alum에서는 $0.22 \mathrm{mg} / \mathrm{L}$ 였다. 투입량을 $0.15 \mathrm{ml} / \mathrm{L}$ 로 높이면 티탄염에서 T-P 농도는 $0.12 \mathrm{mg} / \mathrm{L}$, Alum은 $0.13 \mathrm{mg} / \mathrm{L}$ 였다. 약간의 농도 차이는 있으나 Alum과 티탄염의 인 제거 효율은 유사하였다. S 하수종말처리장의 강화된 T-P 배출 기 준인 $0.2 \mathrm{mg} / \mathrm{L}$ 를 만족하기 위해서는 Alum과 티탄염 모두 0.1 0.15 $\mathrm{ml} / \mathrm{L}$ 정도의 응집제의 투입이 필요하였다. Fig. 2에 응집제 투입량에 따른 $\mathrm{pH}$ 의 변화를 보였다. $\mathrm{pH}$ 6.44인 원수에 응집제 $0.15 \mathrm{ml} / \mathrm{L}$ 를 투 입하면 티탄염의 경우 $\mathrm{pH} 6.17$, Alum은 $\mathrm{pH}$ 6.16으로 낮아졌다. 하 수종말처리장의 운영관리 상 안정적인 $\mathrm{pH}$ 의 유지를 위해 $\mathrm{pH} 6$ 이하 에서 가성소다를 투입하여 $\mathrm{pH}$ 조정을 실시하는데, Alum과 티탄염 모두 $\mathrm{pH} 6$ 이상을 나타내어 가성소다의 투입은 필요하지 않았다.

$\mathrm{C}$ 하수종말처리장 생물학적 처리수에 대해서도 $\mathrm{S}$ 하수처리장 생 물학적 처리수와 동일한 방법으로 실험을 실시하였다. $\mathrm{C}$ 하수종말처 리장의 생물학적 처리수의 $\mathrm{pH}$ 는 $6.76, \mathrm{~T}-\mathrm{P}$ 농도는 $0.41 \mathrm{mg} / \mathrm{L}$ 이었다. 티탄염 투입량에 따른 T-P 농도와 pH 변화를 Fig. 3과 Fig. 4에 나타

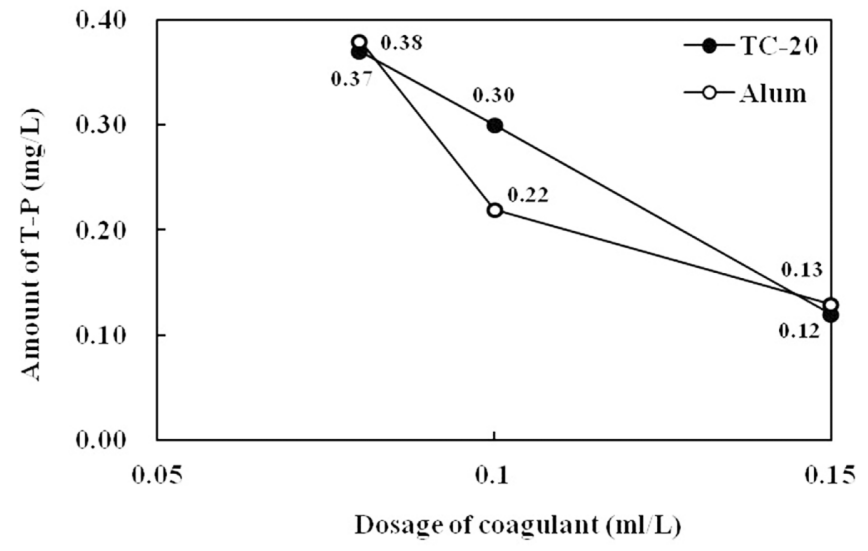

Fig. 1. T-P removal with different Ti-salt concentrations in $\mathrm{S}$ wastewater treatment plant.

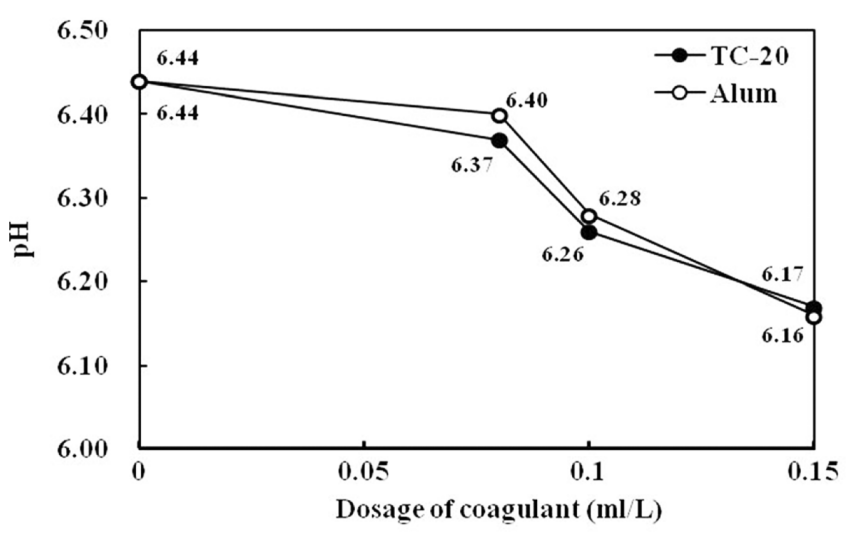

Fig. 2. pH variation with different Ti-salt concentrations in $\mathrm{S}$ wastewater treatment plant.

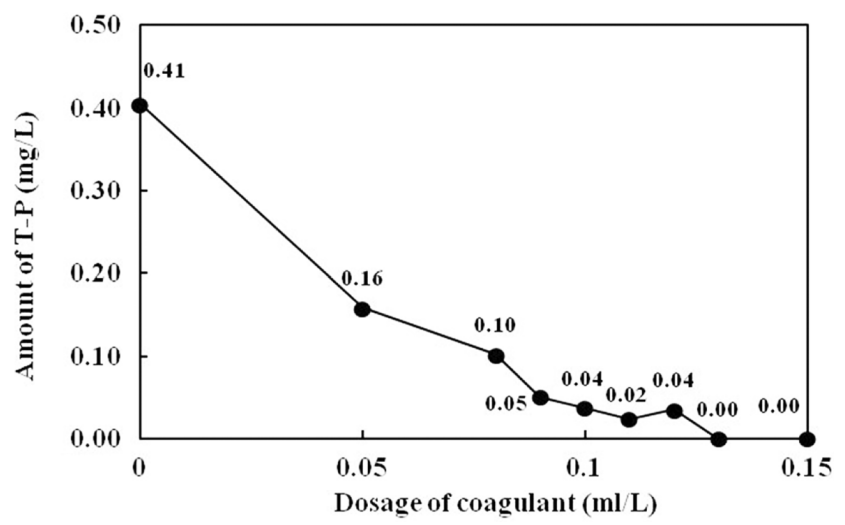

Fig. 3. T-P removal with different Ti-salt concentrations in $\mathrm{C}$ wastewater treatment plant.

내었다. Fig. 3에서 티탄염 투입량이 $0.05 \mathrm{ml} / \mathrm{L}$ 이하에서는 정상적인 플럭 형성이 되지 않았으며, $0.05 \mathrm{ml} / \mathrm{L}$ 를 투입한 경우 플럭이 형성 되었다. T-P 농도는 C 하수종말처리장의 T-P 배출 허용 기준인 0.3 $\mathrm{mg} / \mathrm{L}$ 이하인 $0.16 \mathrm{mg} / \mathrm{L}$ 이였다. 티탄염의 투입량을 점차 증가시키면 T-P 농도는 감소하여 $0.13 \mathrm{ml} / \mathrm{L}$ 이상으로 투입량을 증가시키면 인이 검출되지 않았다. Fig. 4 에서 티탄염 투입량이 $0.12 \mathrm{ml} / \mathrm{L}$ 이상에서는 $\mathrm{pH}$ 가 6 이하로 떨어져서 가성소다에 의한 $\mathrm{pH}$ 조절이 필요하였다. $\mathrm{S}$

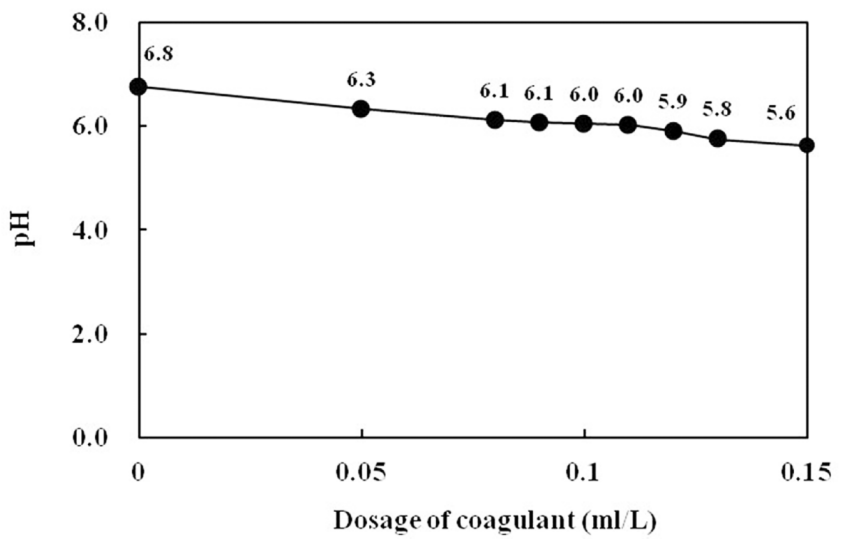

Fig. 4. pH variation with different Ti-salt concentrations in $\mathrm{C}$ wastewater treatment plant.

Korean Chem. Eng. Res., Vol. 51, No. 2, April, 2013 
하수종말처리장과 $\mathrm{C}$ 하수종말처리장 모두 티탄염을 사용하여 인 제 거가 가능하였으며, 기존에 사용하고 있는 Alum과 인 제거 효율 면 에서 큰 차이가 없었다.

\section{3-2. 현장평가}

$\mathrm{S}$ 하수종말처리장은 운용하는 인 제거설비의 방식이 침강식을 사 용하고 있으므로 이와 동일한 구조의 파일롯으로 인 제거 실험을 실 시하였다. S 하수종말처리장의 생물학적 처리수는 $\mathrm{pH}$ 6.4 7.1, T-P $1.4 \sim 1.8 \mathrm{mg} / \mathrm{L}$ 범위에서 파일롯에 유입되었다. 파일롯의 티탄염 투입 량을 $0.1 \sim 0.4 \mathrm{ml} / \mathrm{L}$ 까지 증가시켜 가면서 T-P 농도와 $\mathrm{pH}$ 변화를 조 사하여 Fig. 5와 Fig. 6에 정리하였다. 분석 시료의 취수는 파일롯의 체류시간을 고려하여 투입량을 조정하여 8시간 후에 진행하였다. Fig. 5 에서 정상적인 플럭이 형성되는 투입량은 $0.1 \mathrm{ml} / \mathrm{L}$ 이였으며, 이때 T-P 농도는 $0.76 \mathrm{mg} / \mathrm{L}$ 이였다. Jar 테스트에서 기준치 이하로 분 석된 $0.15 \mathrm{ml} / \mathrm{L}$ 를 투입한 경우에도 $0.47 \mathrm{mg} / \mathrm{L}$ 로 T-P 배출허용 기준 치를 넘었다. 티탄염의 투입량이 $0.35 \mathrm{ml} / \mathrm{L}$ 이상일 때 T-P 배출허용 기준치인 $0.2 \mathrm{mg} / \mathrm{L}$ 를 만족하였다. Fig. 6에서 티탄염의 투입량에 따 른 $\mathrm{pH}$ 의 변화는 Jar 테스트 결과와 유사하였다. T-P 배출허용 기준 치에 만족하는 $0.35 \mathrm{ml} / \mathrm{L}$ 이상에서 $\mathrm{pH} 6$ 이하로 낮아져 가성소다의 투입이 필요하였다. 침강 파일롯 테스트 결과에서도 Jar 테스트 결과 와 유사한 T-P 농도와 $\mathrm{pH}$ 경향이 나타났으나, 티탄염 투입량이 Jar

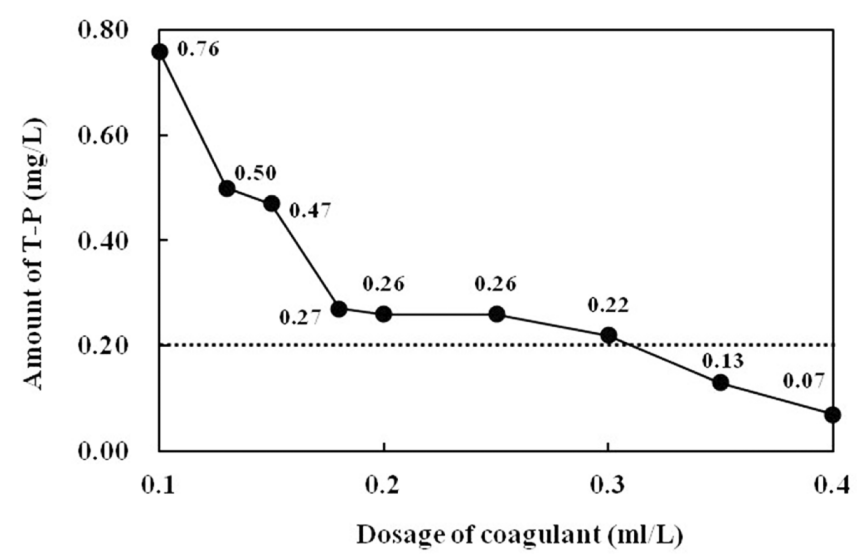

Fig. 5. T-P variation with different Ti-salt concentrations using sedimentation flocculant basin with a pilot scale.

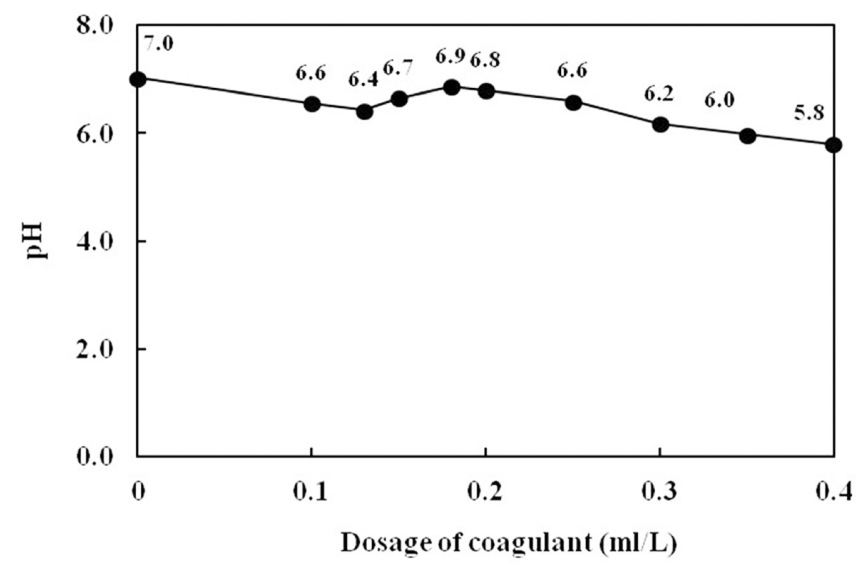

Fig. 6. pH variation with different Ti-salt concentrations using sedimentation flocculant basin with a pilot scale.
테스트에 비하여 증가하였다. Jar 테스트와 다르게 파일롯은 연속 처 리가 되기 때문에 경향은 유사하나 응집제의 투입량 차이가 발생하 는 것으로 판단된다. 또한 안정적인 하수처리공정을 유지하기 위해 서는 적정 투입량보다 많은 응집제의 투입과 이로 인한 가성소다 등 의 중화제 투입이 발생하게 될 것으로 예상된다.

$\mathrm{C}$ 하수종말처리장에서 인 제거를 위하여 운영하는 공정은 가압부 상방식으로, 하부에서 미세 기포를 발생시켜 생성된 플럭을 물 위로 부상시켜 슬러지를 걷어내는 방식이다. $\mathrm{C}$ 하수종말처리장의 현장테 스트는 현장 공정에 기존의 Alum을 대체하여 티탄염을 투입하고 배 출되는 시료를 분석하는 방식으로 진행하였다. 전체 공정을 운영하 는 실험이므로 단시간에 조건 변경이 어려워 Jar 테스트에서 기준치 를 만족한 $0.05 \mathrm{ml} / \mathrm{L}$ 의 티탄염을 투입하는 조건으로 실험을 실시하 였다. $\mathrm{pH}$ 와 T-P 농도의 측정은 T-P 농도가 가장 높은 오후 시간대에 서 진행하였다. Fig. 7와 Fig. 8에서 T-P 농도는 0.12 0.17 mg/L 사 이로 유지되었으며, $\mathrm{pH}$ 도 6.6 6.9로 안정적이었다.

현장 평가에서 티탄염을 응집제로 사용하였을 때 인을 기준치 이 하로 제거할 수 있었으나, 연속 처리 공정에 따른 티탄염 투입량 변 화로 $\mathrm{pH}$ 의 조절이 필요하였다. 하지만, 티탄염을 이용한 인 제거 방 식은 하향침강식이나 가압부상식 모두 적용이 가능한 것으로 판단된다.

\section{3-3. 각 대상별 산화티탄 특성}

티탄염이 포함된 슬러지를 소성하게 되면 온도에 따라 무정형, 아

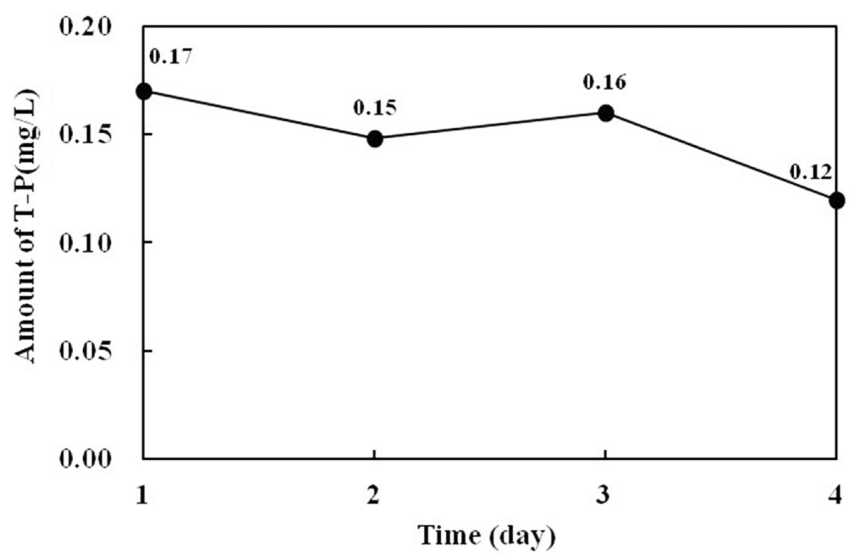

Fig. 7. T-P concentration after Ti-salt flocculation with time using air floatation basin.

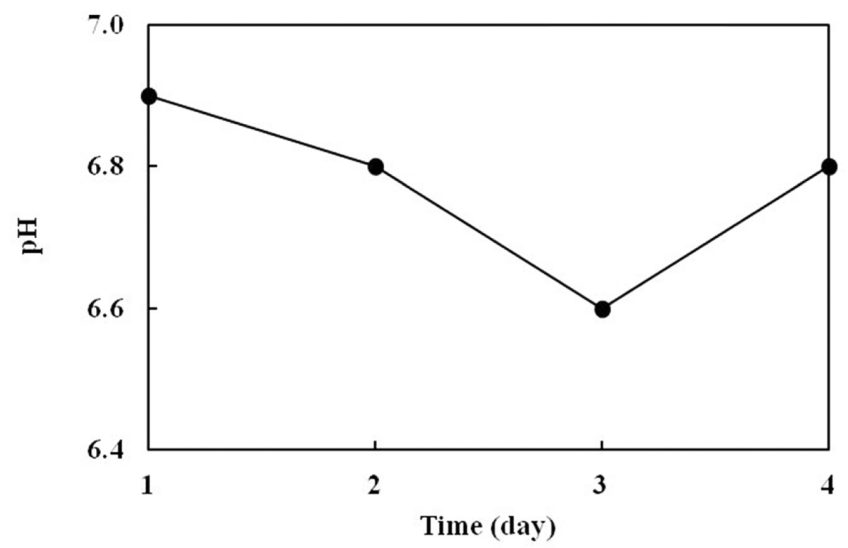

Fig. 8. pH variation with after Ti-salt flocculation with time using air floatation basin. 


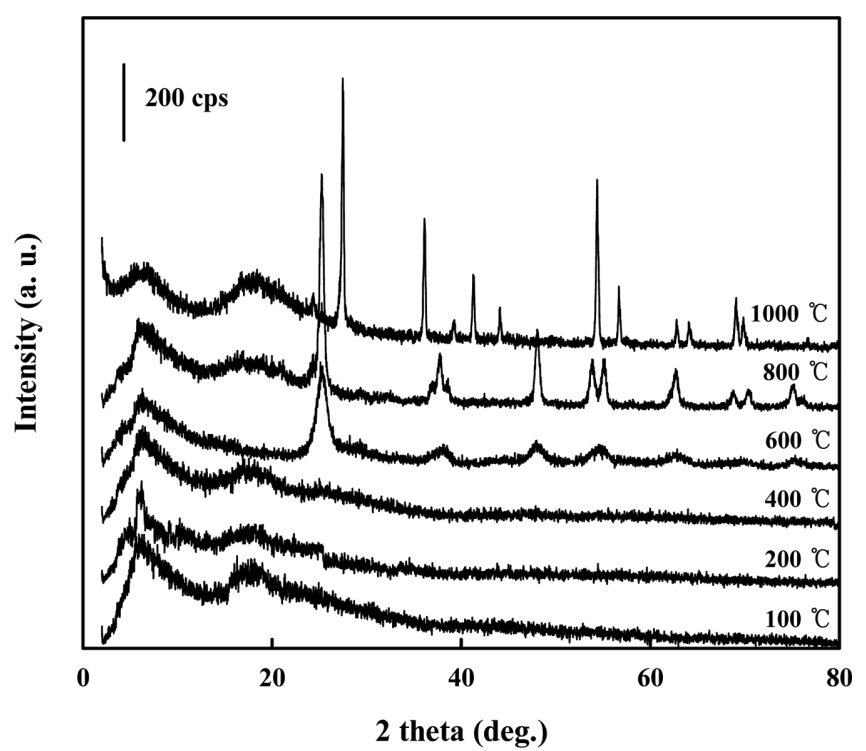

Fig. 9. XRD patterns of the collected sludge with different temperatures.

Table 1. Surface areas of the collected sludge with different temperatures

\begin{tabular}{cc}
\hline \hline Temperature $\left({ }^{\circ} \mathrm{C}\right)$ & $\mathrm{S}_{B E T}\left(\mathrm{~m}^{2} / \mathrm{g}\right)$ \\
\hline 400 & - \\
600 & 76 \\
800 & 6 \\
1000 & 1 \\
\hline
\end{tabular}

나타제, 루타일로 변화하게 된다. 광촉매 활성을 갖는 산화티탄을 획 득하기 위해서는 아나타제 형태의 산화티탄을 제조하여야 한다[10]. $\mathrm{C}$ 하수종말처리장과 S 하수종말처리장에서 현장테스트 후에 배출된 슬러지에 대하여 온도 별로 소성하고 이에 대한 XRD 패턴과 비표 면적을 측정하였다. 두 개의 샘플 모두 같은 결정화 경향을 보여 대 표적인 XRD 패턴을 Fig. 9에, 비표면적을 Table 1에 정리하였다. 소성 온도에 따라 결정 형태가 달라졌다. $400^{\circ} \mathrm{C}$ 까지는 무정형이었으나, $600{ }^{\circ} \mathrm{C}$ 에서 아나타제 피크가 나타났다. $1,000{ }^{\circ} \mathrm{C}$ 에서는 루타일 피크 만 관찰되었다. 소성 온도가 $600 ~ 8000^{\circ} \mathrm{C}$ 사이에서 광촉매 활성이 높은 아나타제 산화티탄이 생성되었다. $400^{\circ} \mathrm{C}$ 이하에서는 유기물이 상당 량 남아 있어 비표면적 측정을 실시하지 않았다. $600^{\circ} \mathrm{C}$ 에서는 76 $\mathrm{m}^{2} / \mathrm{g}$ 으로 표면적이 높았으나, 소성 온도가 더 높아질수록 결정 형태 의 변화와 소결로 인하여 표면적이 급격히 낮아졌다.

생성된 산화티탄의 성분을 분석하기 위하여 $\mathrm{SEM} / \mathrm{EDX}$ 를 이용하 여 분석하였다. 샘플은 $\mathrm{C}$ 하수종말처리장 슬러지와 $\mathrm{S}$ 하수종말처리 장 슬러지를 $300{ }^{\circ} \mathrm{C}$ 에서 일차 건조하고 $600{ }^{\circ} \mathrm{C}$ 에서 소성한 분말을 조사하였다. S 하수종말처리장과 $\mathrm{C}$ 하수종말처리장의 슬러지를 소 성한 분말에 대한 분석 결과를 Table 2에 정리하였다. 다양한 원소들 이 포함되어 있었으나, 두 하수종말처리장의 슬러지를 소성한 분말 모두 주로 $\mathrm{Ti}$ 와 $\mathrm{O}$ 로 구성되어 있었다. $\mathrm{C}$ 하수종말처리장과 $\mathrm{S}$ 하수 종말처리장에서 배출되는 산화티탄의 물성의 차이는 거의 없으며, $\mathrm{S}$ 하수종말처리장 슬러지의 $\mathrm{Ti}$ 의 함량이 $\mathrm{C}$ 하수종말처리장의 $\mathrm{Ti}$ 의 함 량보다 높은 것은 투입된 티탄염의 투입량과 원수에 포함된 무기물 의 양의 차이에서 비롯된 것으로 판단된다. 순도가 높은 산화티탄을 획득하기 위해서는 원수에 무기물 함량을 확인해야 하며, 투입되는
Table 2. SEM/EDX results of titania produced from Ti-salt flocculated sludge in $\mathbf{S}$ and $\mathrm{C}$ wastewater treatment plants

\begin{tabular}{ccc}
\hline \hline \multirow{2}{*}{ Element } & \multicolumn{2}{c}{ Weight (\%) } \\
\cline { 2 - 3 } & S wastewater & C wastewater \\
\hline $\mathrm{C}$ & 2.8 & 1.8 \\
$\mathrm{O}$ & 38.4 & 52.5 \\
$\mathrm{Al}$ & 0.4 & 4.0 \\
$\mathrm{Si}$ & 1.5 & 3.9 \\
$\mathrm{P}$ & 1.9 & - \\
$\mathrm{S}$ & 0.3 & - \\
$\mathrm{Ca}$ & 0.7 & 2.0 \\
$\mathrm{Ti}$ & 54.0 & 35.8 \\
\hline
\end{tabular}

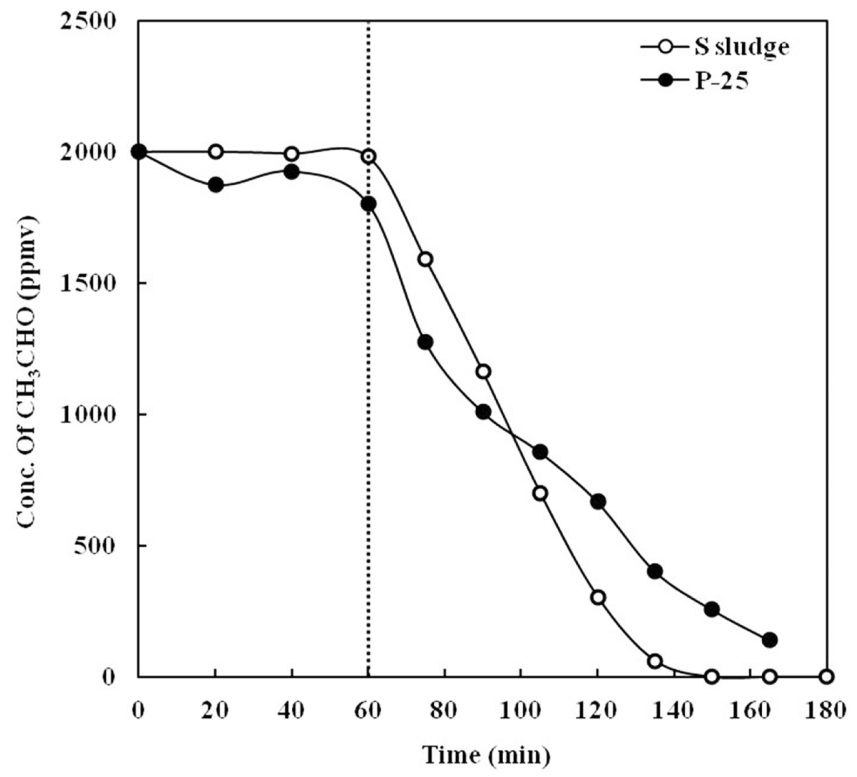

Fig. 10. Photocatalytic activity test using titania produced from Ti-salt flocculated sludge in $\mathrm{S}$ wastewater treatment plant and P-25.

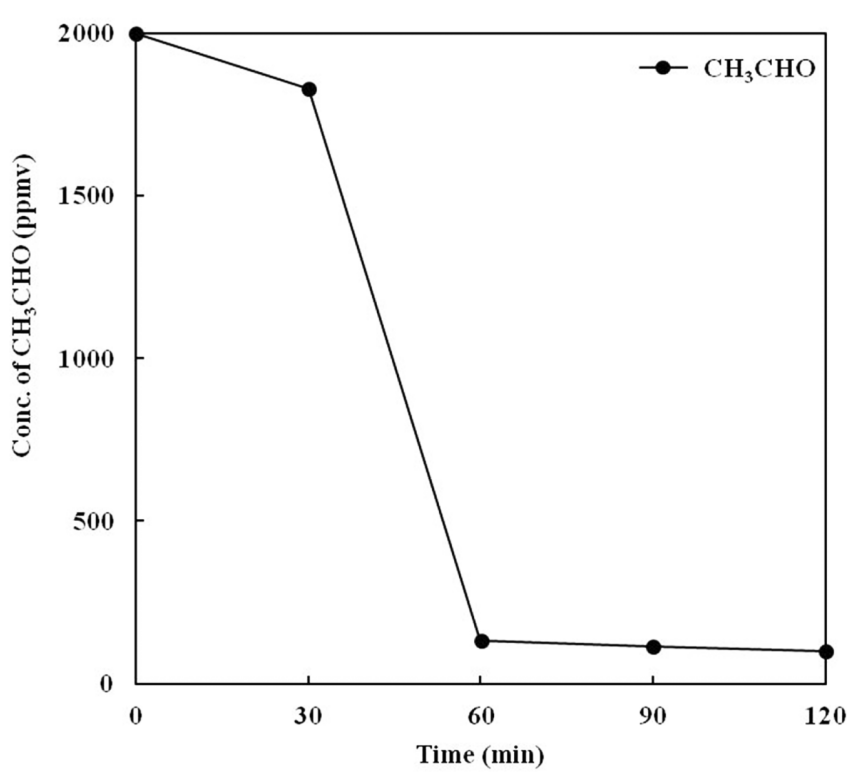

Fig. 11. Photocatalytic activity test using titania produced from Ti-salt flocculated sludge in $\mathrm{C}$ wastewater treatment plant.

Korean Chem. Eng. Res., Vol. 51, No. 2, April, 2013 
티탄염의 투입량을 조절할 필요가 있다.

$\mathrm{S}$ 하수종말처리장에서 생성된 산화티탄과 데구사의 광촉매인 P-25 제품의 아세트알데히드 제거 활성을 Fig. 10에 보였다. UV 램프를 조사하기 전인 60 분까지는 P-25에서 아세트알데히드의 흡착 경향을 보이지만, $\mathrm{S}$ 하수종말처리장에서 생성된 산화티탄에서는 거의 흡착 이 되지 않았다. UV 램프 조사 후 P-25에서는 120 분 경과 후 아세 트알데히드의 분해가 완료되었으며, $\mathrm{S}$ 하수종말처리장 슬러지에서 얻어진 산화티탄은 UV 램프 조사 후 90 분 경과 후 아세트알데히드 분해가 완료되었다.

$\mathrm{C}$ 하수종말처리장 슬러지에서 생성된 산화티탄에 대하여서도 아 세트알데히드 분해 실험을 진행하였다. Fig. 11에서 보는 것과 같이 $\mathrm{UV}$ 램프 조사 후 60 분 경과 후 대부분의 아세트알데히드가 제거되 어 $\mathrm{S}$ 하수종말처리장 슬러지에서 생성된 산화티탄과 유사하였다. $\mathrm{S}$ 하수종말처리장 슬러지에서 생성된 산화티탄과 $\mathrm{C}$ 하수종말처리장에 서 생성된 산화티탄 모두 기존에 시판되는 산화티탄의 광촉매 활성 과 크게 차이가 없거나 오히려 우수한 것을 나타났으며, 광촉매로서 활용가치가 높은 것으로 판단된다.

\section{4. 결 론}

강화되는 수질오염 총량제에 의한 인 제거 공정에서 발생할 수 있는 슬러지 재활용방안을 구축하기 위한 티탄염 응집제의 인 제거 효율 과 생성되는 산화티탄의 특성에 관한 연구에 대한 결론은 다음과 같다.

(1) 응집제로 티탄염을 사용하였을 때 인 제거가 가능하였으며, 인 제거 효율은 기존에 사용하는 Alum과 유사하였다.

(2) 현장 적용 시 유동적인 원수 유입 조건으로 인하여 Jar 테스트 결과와 약간의 차이를 보이나, 티탄염을 이용하여 인을 제거하는데 어려움이 없었다. 현장에서 가장 많이 활용되는 하향침강방식의 침 전조와 가압부상방식의 침전조 모두 기준치 이하로 두 방식에서 모 두 현장 적용이 가능하였다.

(3) 생성된 산화티탄의 성분은 원수에 포함된 무기물과 투입된 티 탄염 성분으로 구성되었다. 생성되는 산화티탄의 순도를 높이기 위 해서는 무기물이 적게 포함된 원수의 선정 및 티탄염 투입량을 증가 시킬 필요가 있었다.

(4) 슬러지에서 생성된 산화티탄의 광촉매 활성은 S 하수종말처리 장과 C 하수종말처리장 슬러지에서 샘플 모두 시판되는 P-25 제품 과 유사하였다. 슬러지에서 생성된 산화티탄도 기존에 사용하는 제 품시장에 대체 사용이 가능할 것으로 판단된다.
(5) 기존에 사용하는 설비의 변경없이 티탄염의 교체만으로 슬러 지의 재활용이 용이하나 슬러지 재활용 설비와의 연계가 필요하므로 현장 상황을 고려하여 적용이 필요할 것으로 판단된다.

\section{감 사}

이 논문은 2012년도 정부(교육과학기술부)의 재원으로 한국연구 재단의 대학중점연구소 지원사업으로 수행된 연구입니다(20090094055).

\section{참고문헌}

1. Holtan, H., Kamp-Nielsen, L. and Stuanes, A. O., "Phosphorous in Soil, Water and Sediment: An Overview,' Hydrobiologia, 170, 19-34(1988).

2. Shon, H. K., Okour, Y., Saliby, I. E., Kim, J. B. and Kim, J.-H., "Effect of Phosphorous on the Properties of Titania Produced from Ti-salt Flocculated Sludge in Water Treatment," J. Nanosci. Nanotechnol., 11, 7456-7458(2011).

3. Kim, J.-H. and Jun, S.-J., "Treatment of Phosphorous in Sewage and Wastewater," KIC News., 14(5), 13-21(2011).

4. Rittmann, B. E. and McCarty, P. L., Environmental Biotechonology, McGraw-Hill, Korea, 579-590(2002).

5. Ministry of Environment, 2010 Environmental Policy Goals, White paper of Environment, Korea(2010).

6. Divakaran, R. and Pillai, V. N., "Flocculation of Kaolinite Suspensions in Water by Chitosan,' Water Res., 35, 3904-3908(2001).

7. Orihuela, D., Meichtrya, V., Pregib, N. and Pizarroa, M., "Shortterm Oral Exposure to Aluminium Decreases Glutathione Intestinal Levels and Changes Enzyme Activities Involved in Its Metabolism," J. Inorg. Biochem., 99, 1871-1878(2005).

8. Shon, H. K., Vigneswaran, S., Kim, I. S., Cho, J., Kim, G. J., Kim, J. B. and Kim, J.-H., "Preparation of Titanium Dioxide $\left(\mathrm{TiO}_{2}\right)$ from Sludge Produced by Titanium Tetrachloride $\left(\mathrm{TiCl}_{4}\right)$ Flocculation of Wastewater,' Environ. Sci. Technol., 41, 1372-1377(2007).

9. American Water Works Association, Standard Methods for the Examination of Water and Wastewater, 16th Ed., Water Environment Federation, USA(1985).

10. Bacsa, R. R. and Kiwi, J., "Effect of Rutile Phase on the Photocatalytic Properties of Nanocrystalline Titania During the Degradation of p-coumaric Acid", Appl. Catal. B: Environ., 16, 19-29 (1998). 